Correspondence

Frank E. Löffler

frank.loeffler@utk.edu

\section{Sphaerochaeta globosa gen. nov., sp. nov. and Sphaerochaeta pleomorpha sp. nov., free-living, spherical spirochaetes}

\author{
Kirsti M. Ritalahti, ${ }^{1,2}$ Shandra D. Justicia-Leon,,4 Kathleen D. Cusick, ${ }^{1}$ \\ Natalia Ramos-Hernandez, ${ }^{3,4}$ Michael Rubin,, 3 Jessica Dornbush ${ }^{3,4}$ \\ and Frank E. Löffler ${ }^{1,2,5}$
}

\author{
1Department of Microbiology, University of Tennessee, Knoxville, TN 37996, USA \\ ${ }^{2}$ Biosciences Division, Oak Ridge National Laboratory, Oak Ridge, TN 37831, USA \\ ${ }^{3}$ School of Biology, Georgia Institute of Technology, Atlanta, GA 30332, USA \\ ${ }^{4}$ School of Civil and Environmental Engineering, Georgia Institute of Technology, Atlanta, \\ GA 30332, USA \\ ${ }^{5}$ Department of Civil and Environmental Engineering, University of Tennessee, Knoxville,
TN 37996, USA
}

Free-living bacteria with spherical cells $0.5-2.5 \mu \mathrm{m}$ in diameter were isolated from freshwater sediment. 16S rRNA gene sequence analysis placed the new isolates within the phylum Spirochaetes ('spirochaetes'). The isolates never displayed a helical morphology or motility. Growth occurred in the presence of $100 \mathrm{mg}^{2}$ ampicillin $\mathrm{I}^{-1}$ in complex and defined mineral salts medium amended with vitamins, yeast extract and monosaccharides, disaccharides or soluble starch as fermentable substrates. Two distinct isolates, designated Buddy ${ }^{\top}$ and $\mathrm{Grapes}^{\top}$, exhibited doubling times of $21 \pm 2$ and $15 \pm 1 \mathrm{~h}$ in glucose-amended medium and grew at 15-37 and $15-30{ }^{\circ} \mathrm{C}$. Optimum growth was observed between 25 and $30{ }^{\circ} \mathrm{C}$ and $\mathrm{pH} 6.5-7.5$, with no growth below $\mathrm{pH} 5$ or above $\mathrm{pH} 10$. Hexose and pentose fermentation yielded ethanol, acetate and formate as major end products. Growth was strictly fermentative and anaerobic, but the isolates tolerated brief oxygen exposure. Nitrate, sulfate, thiosulfate and carbon dioxide were not used as electron acceptors, but soluble $\mathrm{Fe}(\mathrm{III})$ was reduced to $\mathrm{Fe}(\mathrm{II})$ in

glucose-amended medium. The DNA G $+\mathrm{C}$ base contents of isolates Buddy ${ }^{\top}$ and Grapes $^{\top}$ were 45.5-46.4 and 47.0-49.2 mol\%, respectively. Phospholipid fatty acid (PLFA) profiles contained large proportions of $\mathrm{C}_{14: 0}$ and $\mathrm{C}_{16: 0}$ straight-chain saturated fatty acids; $\mathrm{C}_{16: 1} \omega 7 \mathrm{c}$ and $\mathrm{C}_{16: 1} \omega 9 c$ dominated the mono-unsaturated PLFAs in isolate Grapes ${ }^{\top}$, whereas isolate Buddy ${ }^{\top}$ also possessed $\mathrm{C}_{18: 1} \omega 5 c, \mathrm{C}_{18: 1} \omega 7 c$ and $\mathrm{C}_{18: 1} \omega 9 c$ fatty acids. Branched monoenoic acids accounted for up to 12.4 and $30 \%$ of the total PLFA in isolates Grapes ${ }^{\top}$ and Buddy ${ }^{\top}$, respectively. Based on their unique morphological features and the phylogenetic distance from their closest relatives, we propose the new genus, Sphaerochaeta gen. nov., to accommodate the new isolates within the novel species Sphaerochaeta globosa sp. nov. (type strain Buddy ${ }^{\top}=\mathrm{DSM}$ $22777^{\top}=$ ATCC BAA-1886 $^{\top}$ ) and Sphaerochaeta pleomorpha sp. nov. (type strain Grapes ${ }^{\top}$ $=$ DSM $22778^{\top}=$ ATCC BAA $-1885^{\top}$ ). Sphaerochaeta globosa is the type species of the genus.
Abbreviations: PLFA, phospholipid fatty acid; TCE, trichloroethene; TEM, transmission electron microscopy.

The GenBank/EMBL/DDBJ accession numbers for the 16S rRNA gene sequences of strains Buddy ${ }^{\top}$ and Grapes $^{\top}$ are respectively AF357916 and AF357917.

A supplementary figure and table are available with the online version of this paper.
Novel, free-living bacteria with pleomorphic, spherical morphologies form a phylogenetically coherent, monophyletic clade arising from the family Spirochaetaceae. Two isolates were obtained from reductively dechlorinating consortia initiated from sediments of the Red Cedar River (Okemos, MI, USA), and were preliminarily described as 'non-spiral spirochaetes' (Ritalahti \& Löffler, 2002) and subsequently as free-living, pleomorphic spirochaetes (Ritalahti \& Löffler, 2004). The isolates are non-motile 
and replicate in round forms, thus breaking with the prevailing dogma of spirochaete biology, wherein 'all spirochetes are helical or spiral shaped microorganisms with internal organelles of motility called periplasmic flagella' (Paster \& Canale-Parola, 1980; Paster \& Dewhirst, 2000). Such bacteria belong to the class Spirochaetes, order Spirochaetales, which includes the families Brachyspiraceae (genera Brachyspira and Serpulina), Leptospiraceae (genera Leptonema and Leptospira) and Spirochaetaceae (genera Borrelia, Brevinema, Cristispira, Spironema, Treponema and Spirochaeta) (Paster \& Dewhirst, 2000). Based on taxonomic comparisons with other spirochaete lineages, the new isolates warrant a new genus designation. We assert that strains Grapes ${ }^{\mathrm{T}}$ and Buddy ${ }^{\mathrm{T}}$ are members of a seventh genus, for which we propose the name Sphaerochaeta gen. nov., within the Spirochaetaceae.

Sediment samples from the Red Cedar River were collected for the purpose of establishing reductively dechlorinating consortia. Microcosms were amended with $0.05-0.1 \mathrm{mM}$ trichloroethene (TCE) as electron acceptor ( $\mathrm{He}$ et al., 2005). Repeated transfers to defined, completely synthetic, reduced $\left(0.2 \mathrm{mM}\right.$ L-cysteine and $\left.0.2 \mathrm{mM} \mathrm{Na}_{2} \mathrm{~S} .9 \mathrm{H}_{2} \mathrm{O}\right)$ and bicarbonate-buffered dechlorination medium (Sung et al., 2003) amended with TCE, hydrogen and acetate yielded non-methanogenic, ethene-producing cultures. The enrichment process included six consecutive transfers in dechlorination medium amended with 50 or $100 \mu \mathrm{g}$ ampicillin $\mathrm{ml}^{-1}$, a peptidoglycan biosynthesis inhibitor. Isolates were obtained from serially diluted culture suspensions in semisolid $(0.6 \%, \mathrm{w} / \mathrm{v}$, low-melting-point agarose), quarter- or half-strength tryptic soy broth (TSB) medium using the dilution-to-extinction principle (Löffler et al., 2005). This process was repeated before isolated colonies were transferred to Balch tubes with $15 \mathrm{ml}$ half-strength modified TSB (mTSB) medium consisting of $7.4 \mathrm{~g} \mathrm{TSB}^{-1}$ (quarterstrength), $85.6 \mathrm{mM} \mathrm{NaCl}, 1 \mathrm{~g}$ yeast extract $\mathrm{l}^{-1}, 1.8-5 \mathrm{~g}$ Dglucose $\mathrm{l}^{-1}(10-30 \mathrm{mM}$ ), the Wolin vitamin mixture (Wolin et al., 1963) and $1 \mathrm{mM} \mathrm{DTT}$ as reductant. Isolates were maintained $(2 \%, \mathrm{v} / \mathrm{v}$, transfers $)$ in mTSB or the mineral salts dechlorination medium reduced with $1 \mathrm{mM}$ DTT and amended with yeast extract, glucose and vitamins. In semisolid mTSB, strain Grapes ${ }^{\mathrm{T}}$ formed compact, non-pigmented colonies, $1-1.5 \mathrm{~mm}$ in diameter, with irregular, convoluted surfaces after 3 weeks of incubation, which reached $2-4 \mathrm{~mm}$ in diameter after 2 months. Strain Buddy ${ }^{\mathrm{T}}$ produced round, loose, pale colonies, $0.2-0.5 \mathrm{~mm}$ in diameter after 2 weeks of incubation, which grew into lentil-shaped colonies $0.5-2 \mathrm{~mm}$ in diameter and about $0.2 \mathrm{~mm}$ thick in the centre of the colonies after extended incubation periods of several months. During exponential growth in liquid medium, individual cells of strain Grapes ${ }^{\mathrm{T}}$ elicited primarily spherical morphologies, $0.5-2.5 \mu \mathrm{m}$ in diameter, with many cells displaying elongated or crescent shapes and characteristic protrusions (Fig. 1a). Cells also occurred as clusters or aligned along threads like strings of pearls (Fig. 1b). In static mTSB incubations, cells of strain Grapes ${ }^{\mathrm{T}}$ settled and adhered to the glass walls of the culture

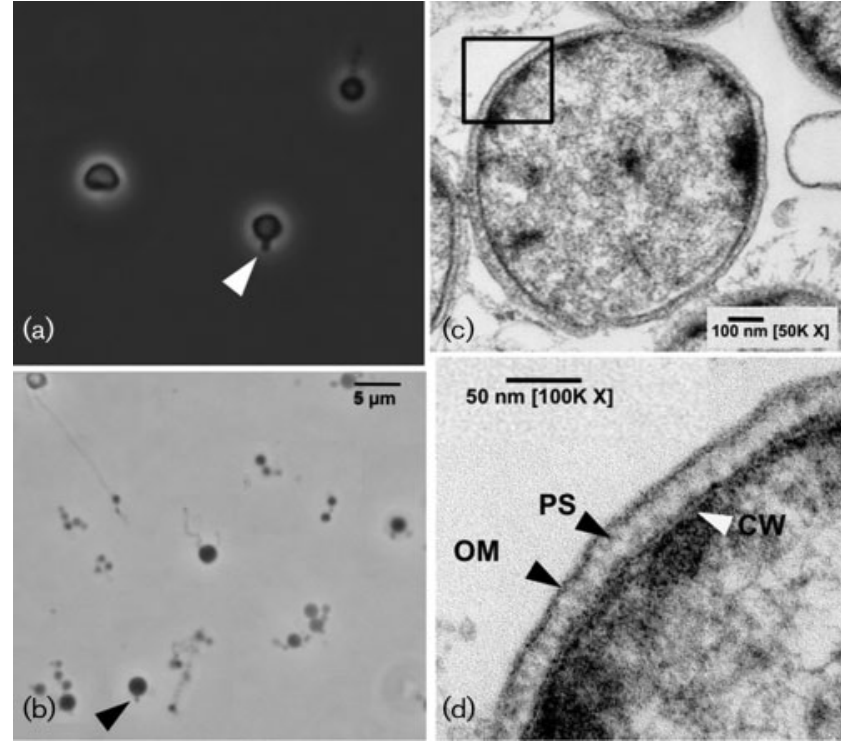

Fig. 1. Cells of strain Grapes $^{\top}$ visualized by phase-contrast microscopy ( $\times 1000$ magnification) $(a, b)$ and TEM (c, d). Protrusions are indicated with arrowheads $(a, b)$. The TEM cross-section (c) shows a single cell. The region inside the rectangle in (c) is magnified in (d) to highlight the cell-wall (CW) architecture. Arrowheads indicate the $\mathrm{CW}$, the periplasmic space (PS) and the outer membrane (OM).

vessels, unlike strain Buddy ${ }^{\mathrm{T}}$. In growing cultures of strain Buddy $^{\mathrm{T}}$, one to ten round to oval cells, $0.5-1.2 \mu \mathrm{m}$ in size, assembled on or within the perimeter of spherical, bubblelike structures, 3-30 $\mu \mathrm{m}$ in diameter (Fig. 2a). Acridine orange staining suggested that only the cells, and not the encapsulating structure, contained DNA (Fig. 2b). Scanning electron microscopy performed with strain Buddy ${ }^{\mathrm{T}}$ corroborated the round cell morphology, and many cells demonstrated the presence of a hook-like feature (Fig. 2c, arrowhead). During transition to stationary phase, cells of the new isolates became smaller and separated into individual cells, and clusters $\left(\mathrm{Grapes}^{\mathrm{T}}\right)$ or larger encapsulated structures $\left(\right.$ Buddy $\left.^{\mathrm{T}}\right)$ were rare. Smaller, individual cells were also common during growth in low-nutrient medium; however, the characteristic aggregates occurred, albeit smaller. The presence of ampicillin (50,100 and $250 \mu \mathrm{g}$ $\mathrm{ml}^{-1}$ ) or rifamycin SV (30 and $60 \mu \mathrm{g} \mathrm{ml}^{-1}$ ) had no effect on growth or on colony morphology in liquid or semi-solid media. Additionally, the isolates were resistant to carbenicillin (50 and $\left.250 \mu \mathrm{g} \mathrm{ml}^{-1}\right)$ and vancomycin (20 and $100 \mu \mathrm{g}$ $\mathrm{ml}^{-1}$ ). Sensitivity was observed to kanamycin, erythromycin, chloramphenicol and tetracycline. Growth occurred in full-strength and diluted mTSB medium and was stimulated by monosodium glutamate $\left(2 \mathrm{~g} \mathrm{l}^{-1}\right)$ and Casamino acids $\left(10 \mathrm{~g}^{-1}\right)$. For the two isolates, lag times in D-glucoseamended mineral salts medium ranged from 2-3 $\left(\right.$ Grapes $^{\mathrm{T}}$ ) to $7-14\left(\right.$ Buddy $\left.^{\mathrm{T}}\right)$ days, and two to three times shorter lag times were observed in mTSB. In half-strength mTSB 


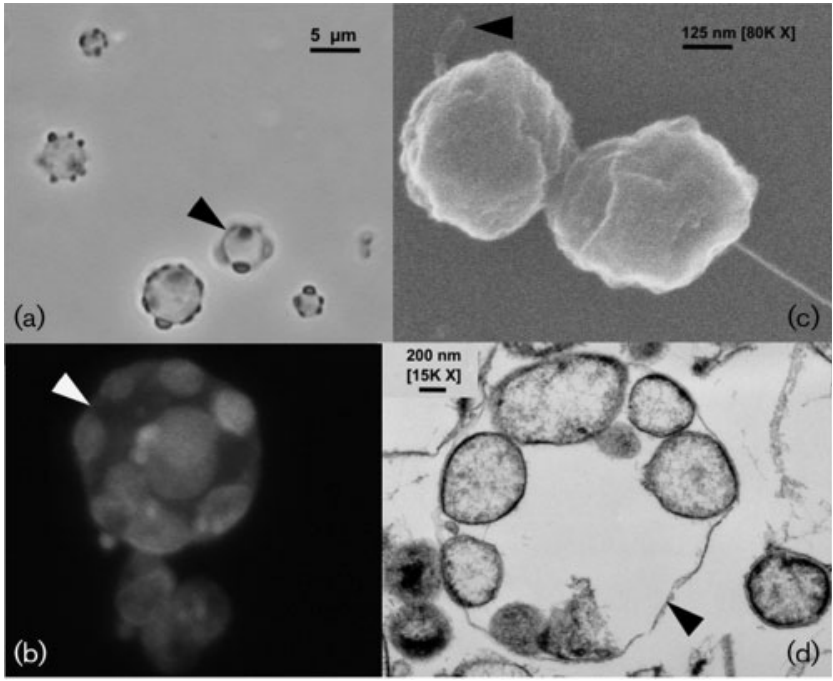

Fig. 2. Cells of strain Buddy ${ }^{\top}$ visualized by phase-contrast microscopy (a), confocal microscopy following acridine orange staining (b), critical-point-dried scanning electron microscopy preparation (c) and TEM cross-section (d). In (a), (b) and (d), a membranous structure that encapsulates one to ten cells of strain Buddy $^{\top}$ is highlighted. In (c), a hook-like protrusion is indicated by an arrowhead.

(without stimulants), doubling times of $15.3 \pm 0.6$ and $20.9 \pm 2.3 \mathrm{~h}$ were observed for strains Grapes ${ }^{\mathrm{T}}$ and Buddy ${ }^{\mathrm{T}}$, respectively. The maximum cell density attained was dependent on the amount of glucose added, rather than the strength of the mTSB medium. In quarter-strength mTSB with $10 \mathrm{mM}$ glucose, strain Buddy ${ }^{\mathrm{T}}$ reached an $\mathrm{OD}_{600}$ of $\sim 0.1$, whereas cultures of strain Grapes ${ }^{\mathrm{T}}$ reached an $\mathrm{OD}_{600}$ of $0.2-0.3$. Other hexoses that supported growth included D-galactose and D-fructose, while D-mannose was used by strain Grapes ${ }^{\mathrm{T}}$ but not strain Buddy ${ }^{\mathrm{T}}$. Other saccharides that supported growth of both isolates included the pentoses D-xylose and L-arabinose, the disaccharide sucrose and the trisaccharides raffinose and melezitose as well as soluble starch. Strain Buddy ${ }^{\mathrm{T}}$ also grew with lactose and maltose, while strain Grapes ${ }^{\mathrm{T}}$ did not. Glucose and xylose fermentation yielded acetate, formate and ethanol, which are characteristic spirochaete carbohydrate fermentation products. $\mathrm{H}_{2}-\mathrm{CO}_{2}$ homoacetogenic growth was not observed in mineral salts medium with a $\mathrm{H}_{2} / \mathrm{CO}_{2}(80: 20$, $\mathrm{v} / \mathrm{v})$ headspace. Citrate $(10 \mathrm{mM})$, ethanol (1.7 and $170 \mathrm{mM})$, methanol (2.5 and $250 \mathrm{mM})$ and glycerol (1.4 and $140 \mathrm{mM}$ ) were not used by either isolate, nor was growth observed with the insoluble substrates glycogen, xylan, cellulose, cellobiose or chitin in liquid medium or supplied at $0.1 \mathrm{~g} \mathrm{l}^{-1}$ suspended in semi-solid mineral salts medium. Electron acceptors including nitrate $(1-5 \mathrm{mM})$, nitrite $(1-5 \mathrm{mM})$, sulfate $(10 \mathrm{mM})$, fumarate $(5 \mathrm{mM})$ and thiosulfate $(10 \mathrm{mM})$ were not reduced in mineral salts medium amended with glucose, propionate, acetate or hydrogen as electron donors. Soluble $\mathrm{Fe}(\mathrm{III})$ (as ferric citrate; $5 \mathrm{mM}$ ) was reduced to $\mathrm{Fe}(\mathrm{II})$ in defined medium amended with $10 \mathrm{mM}$ glucose; however, growth with Fe(III) as electron acceptor could not be demonstrated. Neither isolate dechlorinated TCE and the dechlorinating activity in the enrichments was attributed to Dehalococcoides sp. strain FL2 (He et al., 2005). The results of substrate utilization experiments were verified in at least two independent experiments. Growth was measured by an increase in $\mathrm{OD}_{600}$, microscopic cell counts and analysis of substrate utilization and/or product formation.

In half-strength mTSB with $10 \mathrm{mM}$ glucose, isolates Grapes $^{\mathrm{T}}$ and Buddy ${ }^{\mathrm{T}}$ grew at $15-30$ and $20-37^{\circ} \mathrm{C}$, respectively, with optimum growth at $20-25^{\circ} \mathrm{C}\left(\right.$ Grapes $\left.^{\mathrm{T}}\right)$ and $30{ }^{\circ} \mathrm{C}\left(\right.$ Buddy $\left.^{\mathrm{T}}\right)$. No growth was observed below $10{ }^{\circ} \mathrm{C}$, but cultures remained viable at $4{ }^{\circ} \mathrm{C}$ for at least 3 years, and transfer cultures incubated at $25^{\circ} \mathrm{C}$ grew after a 4-6 day lag period. The $\mathrm{pH}$ optimum ranged from 6.5 to 7.5 , but cultures incubated at $\mathrm{pH} 5$ and $\mathrm{pH} 10$ lost viability (i.e. no growth occurred following transfers to growth medium at $\mathrm{pH}$ 7). Both isolates tolerated oxygen (i.e. air) exposure (i.e. shaking of open culture vessels at 200 r.p.m.) for up to $8 \mathrm{~h}$, and resumed growth following transfers; however, the lag times before the onset of growth in mTSB increased to 57 days $\left(\right.$ Grapes $^{\mathrm{T}}$ ) or several weeks $\left(\right.$ Buddy $\left.^{\mathrm{T}}\right)$, depending on inoculum size and duration of exposure to air. Cultures became non-viable after $24 \mathrm{~h}$ of air exposure. Both isolates tested oxidase- and catalase-negative, and growth in mTSB required a reductant, suggesting that both isolates are strict anaerobes.

During exponential growth, cells stained Gram-negative. Transmission electron microscopy (TEM) of a crosssection of a single cell of strain Grapes ${ }^{\mathrm{T}}$ demonstrated features of a Gram-negative cell wall (Fig. 1c, d). Fig. 1(d) shows the inner cell wall and a double membrane with a periplasmic space between the cell wall and outer membrane. TEM of cross-sections of strain Buddy ${ }^{\mathrm{T}}$ suggested that several cells share a common outer membrane during exponential growth (Fig. 2d). Cell-wall analyses, performed by the DSMZ using chromatographic separation techniques as described previously (MacKenzie, 1987; Rhuland et al., 1955), did not detect diaminopimelic acid in cell hydrolysates; however, only $0.2 \mathrm{mg}$ polymeric substance was obtained from $3.5 \mathrm{~g}$ (wet weight) biomass from strain Grapes ${ }^{T}$, precluding detailed investigations. GC-MS analysis identified leucine, isoleucine, lysine and other amino acids, but diaminopimelic acid and ornithine were absent. Ornithine is the predominant peptidoglycan cross-link in spirochaetes (Joseph et al., 1973), suggesting that the new isolates lack these structural elements, possibly promoting pleomorphy.

Isolates Buddy ${ }^{\mathrm{T}}$ and Grapes ${ }^{\mathrm{T}}$ grown in half-strength mTSB amended with $10 \mathrm{mM}$ glucose were analysed for phospholipid fatty acid (PLFA) profiles by Microbial Insights (http://www.microbe.com; Rockford, TN, USA) using established protocols (White et al., 2005). Similar to other spirochaetes (Franzmann \& Rohde, 1992; Kondo \& Ueta, 
1972; Livermore \& Johnson, 1974), both isolates contained large proportions of even-carbon-number, straightchain saturates, which accounted for $44 \%\left(\right.$ Grapes $\left.^{\mathrm{T}}\right)$ and $31 \%\left(\right.$ Buddy $\left.^{\mathrm{T}}\right)$ of the total PLFA (Supplementary Table S1, available in IJSEM Online). The major saturated PLFAs were $\mathrm{C}_{14.0}$ (26.4 and $13.4 \mathrm{~mol} \%$ in isolates Grapes $^{\mathrm{T}}$ and Buddy ${ }^{\mathrm{T}}$, respectively) and $\mathrm{C}_{16: 0}$ (12.9$16.9 \mathrm{~mol} \%)$. Mono-unsaturated fatty acids made up 39$42 \%$ of the cellular fatty acids. Of the mono-unsaturated PLFAs, $\mathrm{C}_{16: 1}$ was the most abundant, and accounted for $90 \%$ of the monoenoic acids in strain Grapes ${ }^{\mathrm{T}}$, while strain Buddy $^{\mathrm{T}}$ had a slightly smaller total amount of monoenoic acids, and $\mathrm{C}_{16: 1}$ and $\mathrm{C}_{18: 1}$ were equally abundant. Branched monoenoic acids $\left(\mathrm{br}-\mathrm{C}_{15: 1}\right.$, br- $\mathrm{C}_{17: 1}$ and br- $\mathrm{C}_{19: 1}$ ) accounted for nearly $30 \%$ and $12.4 \%$ of the total PLFA in Buddy ${ }^{T}$ and Grapes ${ }^{T}$, respectively. These amounts correlated inversely with the abundance of straight-chain mono-unsaturated $\mathrm{C}_{16: 1}$ fatty acids, which were higher in Grapes ${ }^{\mathrm{T}}$ and lower in Buddy ${ }^{\mathrm{T}}$ (Supplementary Table S1). Odd-carbon-number iso-branched and anteisobranched PLFAs were not detected.

Motility was not observed during any stage of growth or under non-growth conditions in liquid or semi-solid (0.1$0.6 \%$ low-melting-point agarose) medium under various substrate, $\mathrm{pH}$ and temperature regimes. Silver nitrate staining never revealed flagella (i.e. periplasmic flagella) in either isolate. Primers targeting flaA (Li et al., 2008) failed to produce amplicons with template DNA from either isolate, whereas DNA from a Spirochaeta stenostrepta strain yielded amplicons of the expected size.

The two isolates had distinct rep-PCR profiles (Rademaker et al., 2000), which remained consistent over time, suggesting genome stability. The DNA G $+\mathrm{C}$ base contents of strains Buddy $^{\mathrm{T}}$ and Grapes ${ }^{\mathrm{T}}$ were respectively 45.5-46.4 and 47.0$49.2 \mathrm{~mol} \%$ (determined as described by Mesbah et al., 1989). Phylogenetic analysis based on 1500 positions of the $16 \mathrm{~S}$ rRNA gene revealed that the sequences of strains Buddy ${ }^{\mathrm{T}}$ and Grapes $^{\mathrm{T}}$ were $95.5 \%$ similar by pairwise alignment performed with Geneious Pro 5.0.2 software and the EzTaxon tool (http://www.eztaxon.org; Chun et al., 2007). Additional isolation efforts yielded isolate JEL1 (GenBank accession no. DQ833402; 99.4\% 16S rRNA gene similarity to Grapes ${ }^{\mathrm{T}}$ ) from Alaska's King Salmon River. This isolate exhibited a PLFA profile similar to that of strain Grapes ${ }^{\mathrm{T}}$ (Supplementary Table S1). Another isolate, strain TQ1, obtained from sediments of Michigan's Tahquamenon River (DQ833400), shared 95.3 and $95.6 \% 16 \mathrm{~S}$ rRNA gene sequence similarity with strains Grapes ${ }^{\mathrm{T}}$ and Buddy ${ }^{\mathrm{T}}$, respectively. BLAST analysis revealed that $16 \mathrm{~S}$ rRNA gene sequences affiliated with strains Grapes $^{\mathrm{T}}$ and Buddy ${ }^{\mathrm{T}}$ have been found in a variety of environments, including a hypersaline, ice-sealed Antarctic lake (GenBank accession no. GQ167322), the microflora of kusawa gravy, a fermented Japanese sauce (AB003448, AB003434; Satomi et al., 1997), an ethylbenzeneutilizing consortium (AB062692-AB062695), oil reservoirs (AY570600, AY570571; Grabowski et al., 2005), dechlorinating enrichment cultures [EU169845 (Chung \& Rittmann,
2007), AF349763 (Gu et al., 2004), AJ249227 and AF349763], a methanogenic, glucose-fed bioreactor with highly abundant 'spirochaetal' 16S rRNA gene sequences, but with a predominance of round cells (Fernandez et al., 2000), and a cellulose- and methanol-utilizing digester (EF586024, EF559111) (Supplementary Fig. S1). Phylogenetic affiliation with the spirochaetes was determined by BLAST analysis against the GenBank nr database and the RDP (Cole et al., 2005). Unrooted phylogenetic trees of $16 \mathrm{~S}$ rRNA gene sequences of spirochaete type strains (Fig. 3, Supplementary Fig. S1) were generated using the Geneious software and the PhyML tree plugin (Drummond et al., 2009; Guindon \& Gascuel, 2003). Alignment algorithms utilized MUSCLE with the neighbour-joining or UPGMA clustering method and CLUSTAL W weighting scheme (1352 aligned bases). All approaches yielded similar results, with isolates Buddy ${ }^{\mathrm{T}}$, Grapes $^{\mathrm{T}}$, JEL1 and TQ1 forming a distinct cluster within the family Spirochaetaceae (Fig. 3). Supplementary Fig. S1 highlights $16 \mathrm{~S}$ rRNA gene clone sequences related to those of the new isolates and aligned with representative Spirochaeta and Treponema sequences.

Organisms with $<98.5 \% 16 \mathrm{~S}$ rRNA gene sequence similarity have been found to share less than $95 \%$ average nucleotide identity and therefore would not belong to the same species (Cole et al., 2010; Stackebrandt et al., 2002). The closest relative with confirmed spirochaete-characteristic motility and spiral morphology is Spirochaeta smaragdinae DSM $11293^{\mathrm{T}}$ (GenBank accession no. U80597), a free-living, anaerobic, mesophilic, carbohydrate-fermenter (Magot et al., 1997), which exhibits 85.1 and $85.2 \% 16 \mathrm{~S}$ rRNA gene sequence similarity to Buddy ${ }^{\mathrm{T}}$ and Grapes ${ }^{\mathrm{T}}$, respectively. Phylogenetic analysis based on the comparison of sequences with $>1200$ 16S rRNA gene nucleotide positions available in the RDP (Cole et al., 2005) demonstrated that the new isolates, along with a number of environmental clone sequences, formed a monophyletic cluster arising from the genus Spirochaeta (Fig. 3). The genus Spirochaeta comprises facultatively or obligately anaerobic, free-living spirochaetes that are often isolated from aquatic or marine environments, including deep-sea sediments (Canale-Parola, 1984). Only two isolates, Spirochaeta coccoides SPN1 ${ }^{\mathrm{T}}$ (GenBank accession no. AJ698092; about $11 \% 16 \mathrm{~S}$ rRNA gene sequence divergence from the novel isolates) obtained from the termite hindgut (Dröge et al., 2006) and Spirochaeta sp. ACE-P (M87055; $13.3 \%$ sequence divergence), an unusual, obligately psychrophilic, wall-less spirochaete from Ace Lake, Antarctica (Franzmann \& Dobson, 1992), have been described with round rather than spiral morphology. As shown in Fig. 3 and Supplementary Fig. S1, the new isolates share a common line of descent with Spirochaeta but exhibit $>10 \% 16 \mathrm{~S}$ rRNA gene sequence divergence. Based on the unique taxonomic features, we propose that the new isolates belong to a new genus, Sphaerochaeta gen. nov., as the type strains of two novel species, Sphaerochaeta pleomorpha sp. nov. and Sphaerochaeta globosa sp. nov. As non-motile spirochaetes with round cells have been described as members of the 


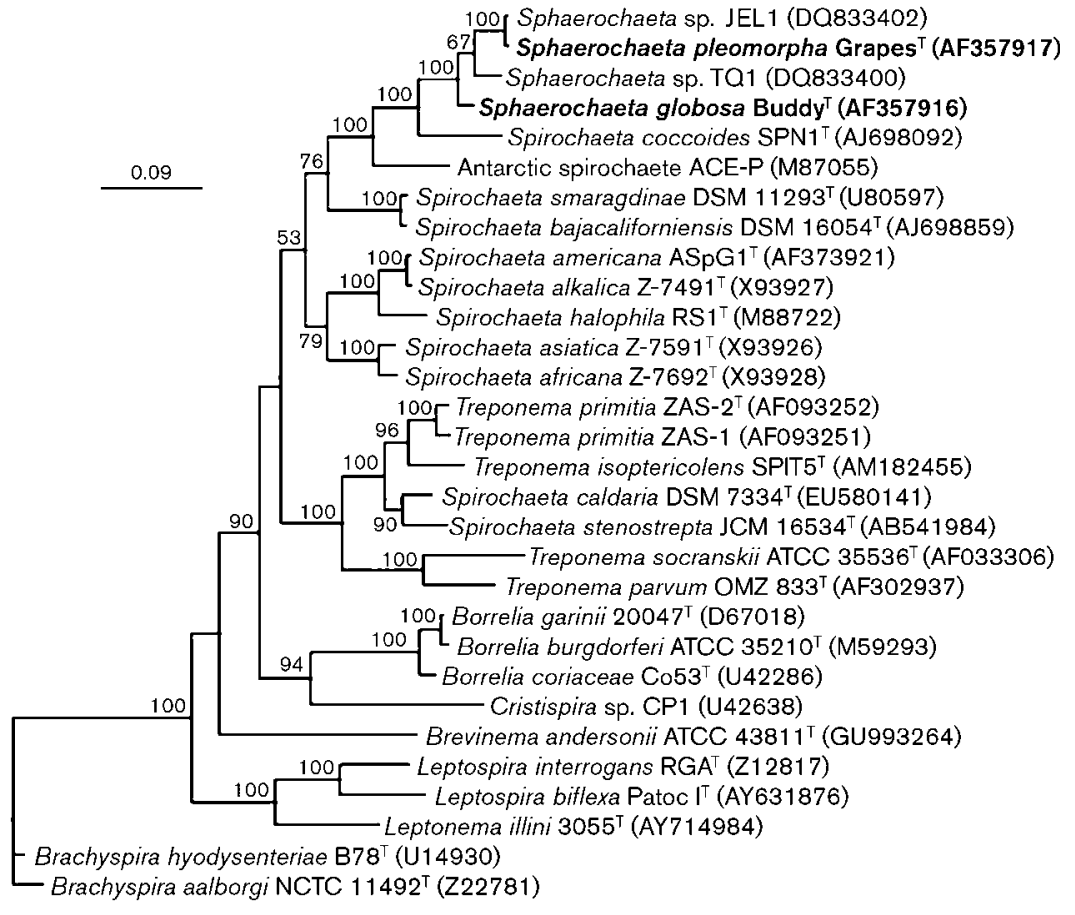

Fig. 3. Phylogeny of isolates Grapes ${ }^{\top}$, Buddy ${ }^{\top}$, JEL1 and TQ1 among related species of the family Spirochaetaceae based on a maximumlikelihood analysis of nearly complete $16 \mathrm{~S}$ rRNA gene sequences. No culture or sequence is available for Spirochaeta plicatilis, the type species of the genus Spirochaeta; a request to replace this species with Spirochaeta stenostrepta as the type species (Canale-Parola, 1981) was denied (Wayne, 1982). An unrooted tree of the Spirochaetaceae is shown, with bootstrap values greater than $50 \%$ expressed as percentages of 1000 replications. Bar, 9 substitutions per 100 sequence positions. genera Spirochaeta and Sphaerochaeta, future comparative analyses that include more isolates may justify reclassification of Spirochaeta coccoides $\mathrm{SPN1}^{\mathrm{T}}$ and Spirochaeta sp. ACE-P as members of the genus Sphaerochaeta.

\section{Description of Sphaerochaeta gen. nov.}

Sphaerochaeta [Sphae.ro.chae'ta. Gr. n. sphaira (Latin transliteration sphaera), a sphere; Gr. fem. n. chaitê (Latin transliteration chaeta), long flowing hair; N.L. fem. n. Sphaerochaeta round cells along threads of hair, indicative of a round morphology with a derivation from spirochaetal ancestry].

Spherical cells, $0.4-2.5 \mu \mathrm{m}$ in diameter. Pleomorphic; cells of different sizes and shapes are observed during growth. Spiral morphology not observed. Cells are non-motile, without flagella, periplasmic or otherwise. Cells stain Gram-negative and do not have ornithine or lysine peptidoglycan cross-links. Mesophilic. Neutrophilic. Chemoheterotrophic anaerobes; fermentative growth is observed with carbohydrates including pentose and hexose monosaccharides, disaccharides and soluble starch. End products of glucose fermentation include acetate, formate and ethanol. Growth is stimulated by yeast extract, Casamino acids and vitamins. DNA G $+C$ content is 45-48 mol\%. Oxidase- and catalase-negative. Phylogenetic position is in the family Spirochaetaceae, order Spirochaetales, class Spirochaetes of the phylum Spirochaetes. Sphaerochaeta globosa is the type species.

\section{Description of Sphaerochaeta globosa sp. nov.}

Sphaerochaeta globosa (glo.bo'sa. L. fem. adj. globosa sphereshaped, reflecting the characteristic morphology, wherein round cells form on spherical 'bubbles' during exponential growth).
Has the following properties in addition to those described for the genus. Cells in exponential growth phase occur as spherical aggregates, $3-25 \mu \mathrm{m}$ in diameter, comprising one to ten cells. A membranous structure surrounds cell aggregates. Cells carry a single, hook-like protrusion. Prefers low-nutrient conditions. Fermentable substrates include D-galactose, D-glucose, D-fructose, D-xylose, sucrose, maltose, lactose, raffinose, melezitose and soluble starch. L-Arabinose is used poorly; D-mannose is not used for growth, nor are glycogen, cellulose, chitin or xylan. Major cellular fatty acids are $\mathrm{C}_{14: 0}, \mathrm{C}_{16: 0}, \mathrm{C}_{16: 1} \omega 7 c$, $\mathrm{C}_{18: 1} \omega 7 c, \mathrm{C}_{18: 1} \omega 9 c$ and br- $\mathrm{C}_{17: 1} \omega 7 c$ (Supplementary Table S1). Grows at $20-35{ }^{\circ} \mathrm{C}$, with irreversible inactivation above $40{ }^{\circ} \mathrm{C}$. The DNA G $+\mathrm{C}$ content of the type strain is $46.5 \pm 0.4 \mathrm{~mol} \%$.

The type strain, Buddy ${ }^{\mathrm{T}}\left(=\right.$ ATCC BAA- $1886^{\mathrm{T}}=$ DSM $22777^{\mathrm{T}}$ ), was isolated from black, anoxic sediments of the Red Cedar River in Okemos, MI, USA ( $42^{\circ} 41^{\prime} 49.72^{\prime \prime} \mathrm{N}$ $\left.84^{\circ} 22^{\prime} 43.67^{\prime \prime} \mathrm{W}\right)$.

\section{Description of Sphaerochaeta pleomorpha sp. nov.}

Sphaerochaeta pleomorpha (ple'o.mor'pha. Gr. adv. pleon more; Gr. n. morphe shape, form; N.L. adj. pleomorpha having many shapes and sizes, pleomorphic, reflecting the characteristic morphological progression during phases of growth).

Has the following properties in addition to those described for the genus. Chains of cells, $0.8-2 \mu \mathrm{m}$ in size, predominate during exponential growth. Cells carry a single, hook-like protrusion. Fermentable substrates 
include D-galactose, D-glucose, D-fructose, D-mannose, Dxylose, sucrose, raffinose, melezitose and soluble starch. L-Arabinose is used poorly; maltose, lactose, glycogen, cellulose, chitin and xylan are not utilized as growth substrates. Major cellular fatty acids are $\mathrm{C}_{14: 0}, \mathrm{C}_{16: 0}$, $\mathrm{C}_{16: 1} \omega 7 c$ and br- $\mathrm{C}_{17: 1} \omega 7 c$ (Supplementary Table S1). Grows at $15-30{ }^{\circ} \mathrm{C}$, with irreversible inactivation above $35{ }^{\circ} \mathrm{C}$. Exhibits biofilm formation on glass surfaces. The DNA G + C content of the type strain is $48.1 \pm 1.1 \mathrm{~mol} \%$.

The type strain, Grapes ${ }^{\mathrm{T}}\left(=\right.$ ATCC BAA- $1885^{\mathrm{T}}=\mathrm{DSM}$ $22778^{\mathrm{T}}$ ), was isolated from black, anoxic sediments of the Red Cedar River in Okemos, MI, USA ( $42^{\circ} 41^{\prime} 49.72^{\prime \prime} \mathrm{N}$ $84^{\circ} 22^{\prime} 43.67^{\prime \prime} \mathrm{W}$ ).

\section{ACKNOWLEDGEMENTS}

We are indebted to John Breznak for encouragement and many helpful discussions, and Noha M. Mesbah for determining the G+C content of isolates Buddy and Grapes. Appreciation to all the microscopists who participated in imaging, particularly Shirley Owens, Jeanette Taylor, and the late Rob Apkarian. Thanks also to Jarrod Pollock for help with the iron analysis. This material is based upon work supported by the National Science Foundation under grant no. 0919251.

\section{REFERENCES}

Canale-Parola, E. (1981). Proposal that Spirochaeta stenostrepta Zuelzer replace Spirochaeta plicatilis Ehrenberg as the type species of the genus Spirochaeta Ehrenberg. Request for an Opinion. Int J Syst Bacteriol 31, 105-106.

Canale-Parola, E. (1984). The spirochetes. In Bergey's Manual of Systematic Bacteriology, vol. 1, pp. 38-70. Edited by N. R. Krieg \& J. G. Holt. Baltimore: Williams \& Wilkins.

Chun, J., Lee, J.-H., Jung, Y., Kim, M., Kim, S., Kim, B. K. \& Lim, Y.-W. (2007). EzTaxon: a web-based tool for the identification of prokaryotes based on 16S ribosomal RNA gene sequences. Int J Syst Evol Microbiol 57, 2259-2261.

Chung, J. \& Rittmann, B. E. (2007). Bio-reductive dechlorination of 1,1,1-trichloroethane and chloroform using a hydrogen-based membrane biofilm reactor. Biotechnol Bioeng 97, 52-60.

Cole, J. R., Chai, B., Farris, R. J., Wang, Q., Kulam, S. A., McGarrell, D. M., Garrity, G. M. \& Tiedje, J. M. (2005). The Ribosomal Database Project (RDP-II): sequences and tools for high-throughput rRNA analysis. Nucleic Acids Res 33, D294-D296.

Cole, J. R., Konstantinidis, K., Farris, R. J. \& Tiedje, J. M. (2010). Microbial diversity and phylogeny: extending from rRNAs to genomes. In Environmental Molecular Microbiology, pp. 1-20. Edited by W.-T. Liu \& J. K. Jansson. Wymondham, UK: Caister Academic Press.

Dröge, S., Fröhlich, J., Radek, R. \& König, H. (2006). Spirochaeta coccoides sp. nov., a novel coccoid spirochete from the hindgut of the termite Neotermes castaneus. Appl Environ Microbiol 72, 392-397.

Drummond, A. J., Ashton, B., Cheung, M., Heled, J., Kearse, M., Moir, R., Stones-Havas, S., Thierer, T. \& Wilson, A. (2009). Geneious version 4.7. http://www.geneious.com/

Fernandez, A. S., Hashsham, S. A., Dollhopf, S. L., Raskin, L., Glagoleva, O., Dazzo, F. B., Hickey, R. F., Criddle, C. S. \& Tiedje, J. M. (2000). Flexible community structure correlates with stable community function in methanogenic bioreactor communities perturbed by glucose. Appl Environ Microbiol 66, 4058-4067.

Franzmann, P. D. \& Dobson, S. J. (1992). Cell wall-less, free-living spirochetes in Antarctica. FEMS Microbiol Lett 76, 289-292.

Franzmann, P. D. \& Rohde, M. (1992). Characteristics of a novel, anaerobic, mycoplasma-like bacterium from Ace Lake, Antarctica. Antarct Sci 4, 155-162.

Grabowski, A., Nercessian, O., Fayolle, F., Blanchet, D. \& Jeanthon, C. (2005). Microbial diversity in production waters of a lowtemperature biodegraded oil reservoir. FEMS Microbiol Ecol 54, 427-443.

Gu, A. Z., Hedlund, B. P., Staley, J. T., Strand, S. E. \& Stensel, H. D. (2004). Analysis and comparison of the microbial community structures of two enrichment cultures capable of reductively dechlorinating TCE and cis-DCE. Environ Microbiol 6, 45-54.

Guindon, S. \& Gascuel, O. (2003). A simple, fast, and accurate algorithm to estimate large phylogenies by maximum likelihood. Syst Biol 52, 696-704.

He, J., Sung, Y., Krajmalnik-Brown, R., Ritalahti, K. M. \& Löffler, F. E. (2005). Isolation and characterization of Dehalococcoides sp. strain FL2, a trichloroethene (TCE)- and 1,2-dichloroethene-respiring anaerobe. Environ Microbiol 7, 1442-1450.

Joseph, R., Holt, S. C. \& Canale-Parola, E. (1973). Peptidoglycan of free-living anaerobic spirochetes. J Bacteriol 115, 426-435.

Kondo, E. \& Ueta, N. (1972). Composition of fatty acids and carbohydrates in Leptospira. J Bacteriol 110, 459-467.

Li, C., Wolgemuth, C. W., Marko, M., Morgan, D. G. \& Charon, N. W. (2008). Genetic analysis of spirochete flagellin proteins and their involvement in motility, filament assembly, and flagellar morphology. J Bacteriol 190, 5607-5615.

Livermore, B. P. \& Johnson, R. C. (1974). Lipids of the Spirochaetales: comparison of the lipids of several members of the genera Spirochaeta, Treponema, and Leptospira. J Bacteriol 120, 1268-1273.

Löffler, F. E., Sanford, R. A. \& Ritalahti, K. M. (2005). Enrichment, cultivation, and detection of reductively dechlorinating bacteria. Methods Enzymol 397, 77-111.

MacKenzie, S. L. (1987). Gas chromatographic analysis of amino acids as the N-heptafluorobutyryl isobutyl esters. J Assoc Off Anal Chem 70, 151-160.

Magot, M., Fardeau, M. L., Arnauld, O., Lanau, C., Ollivier, B., Thomas, P. \& Patel, B. K. (1997). Spirochaeta smaragdinae sp. nov., a new mesophilic strictly anaerobic spirochete from an oil field. FEMS Microbiol Lett 155, 185-191.

Mesbah, M., Premachandran, U. \& Whitman, W. B. (1989). Precise measurement of the $\mathrm{G}+\mathrm{C}$ content of deoxyribonucleic acid by high-performance liquid chromatography. Int J Syst Bacteriol 39, 159167.

Paster, B. J. \& Canale-Parola, E. (1980). Involvement of periplasmic fibrils in motility of spirochetes. J Bacteriol 141, 359-364.

Paster, B. J. \& Dewhirst, F. E. (2000). Phylogenetic foundation of spirochetes. J Mol Microbiol Biotechnol 2, 341-344.

Rademaker, J. L., Hoste, B., Louws, F. J., Kersters, K., Swings, J., Vauterin, L., Vauterin, P. \& de Bruijn, F. J. (2000). Comparison of AFLP and rep-PCR genomic fingerprinting with DNA-DNA homology studies: Xanthomonas as a model system. Int J Syst Evol Microbiol 50, 665-677.

Rhuland, L. E., Work, E., Denman, R. F. \& Hoare, D. S. (1955). The behavior of the isomers of $\alpha, \varepsilon$-diaminopimelic acid on paper chromatograms. J Am Chem Soc 77, 4844-4846.

Ritalahti, K. M. \& Löffler, F. E. (2002). Ecology and characterization of novel, free-living, non-spiral spirochetes. In Abstracts of the 102nd 
General Meeting of the American Society for Microbiology, 19-23 May 2002, Salt Lake City, UT, USA. Washington, DC: American Society for Microbiology.

Ritalahti, K. M. \& Löffler, F. E. (2004). Characterization of novel freeliving pleomorphic spirochetes [FLiPS]. In Abstracts of the 10th International Symposium on Microbial Ecology, 22-27 August 2004, Cancun, Mexico. Wageningen: International Society for Microbial Ecology.

Satomi, M., Kimura, B., Takahashi, G. \& Fuji, T. (1997). Microbial diversity in Kusaya gravy. Fish Sci 63, 1019-1023.

Stackebrandt, E., Frederiksen, W., Garrity, G. M., Grimont, P. A. D., Kämpfer, P., Maiden, M. C. J., Nesme, X., Rosselló-Mora, R., Swings, J. $\&$ other authors (2002). Report of the ad hoc committee for the reevaluation of the species definition in bacteriology. Int J Syst Evol Microbiol 52, 1043-1047.
Sung, Y., Ritalahti, K. M., Sanford, R. A., Urbance, J. W., Flynn, S. J., Tiedje, J. M. \& Löffler, F. E. (2003). Characterization of two tetrachloroethene-reducing, acetate-oxidizing anaerobic bacteria and their description as Desulfuromonas michiganensis sp. nov. Appl Environ Microbiol 69, 2964-2974.

Wayne, L. G. (1982). Actions of the Judicial Commission of the International Committee on Systematic Bacteriology on requests for opinions published between July 1979 and April 1981. Int J Syst Bacteriol 32, 464-465.

White, D. C., Geyer, R., Peacock, A. D., Hedrick, D. B., Koenigsberg, S. S., Sung, Y., He, J. \& Löffler, F. E. (2005). Phospholipid furan fatty acids and ubiquinone-8: lipid biomarkers that may protect Dehalococcoides strains from free radicals. Appl Environ Microbiol 71, 8426-8433.

Wolin, E. A., Wolin, M. J. \& Wolfe, R. S. (1963). Formation of methane by bacterial extracts. J Biol Chem 238, 2882-2886. 